\title{
Komparasi Metode AHP-SAW dan AHP-WP pada SPK Penentuan E-Commerce Terbaik di Indonesia
}

\author{
Gede Surya Mahendra ${ }^{\text {a1 }}$, Putu Gede Surya Cipta Nugraha ${ }^{\text {a2 }}$ \\ ${ }^{a}$ Program Studi Teknik Informatika, STIMIK STIKOM Indonesia \\ Jalan Tukad Pakerisan No 97, Denpasar, Bali, Indonesia \\ ${ }^{1}$ gede.mahendra@stiki-indonesia.ac.id \\ ${ }^{2}$ surya.ciptadstiki-indonesia.ac.id
}

\begin{abstract}
Abstrak
E-Commerce di Indonesia diprediksi akan berkembang sangat pesat dan menjadi market leader di Asia Tenggara. 96\% pengguna internet di Indonesia telah menggunakan E-Commerce. Industri E-Commerce global menunjukkan peningkatan signifikan dalam lalu lintas $w e b$ harian lebih dari 50\% pada masa pandemi COVID-19, diakibatkan social distancing dan physical distancing oleh konsumen. Dari maraknya persaingan, banyak pertimbangan dari konsumen, sulitnya memilih produk membuat konsumen masih bingung dalam memilih E-Commerce yang tepat untuk melakukan transaksi. Untuk mengatasinya, sistem pendukung keputusan (SPK) dapat digunakan untuk memberikan rekomendasi dalam memilih E-Commerce yang tepat. Dalam penelitian ini metode yang akan digunakan adalah kombinasi dari AHP-SAW dan AHP-WP dengan framework CRISP-DM. E-Commerce terbaik di Indonesia yang ditentukan berdasarkan bobot kriteria dari 5 narasumber aktif pengguna E-Commerce serta penilaian alternatif berdasarkan survei eIQ Consumer Pulse 2019. Hasil dari penelitian ini menyatakan bahwa alternatif "Bukalapak" merupakan E-Commerce terbaik dengan nilai preferensi AHP-SAW sebesar 0,8543 dan AHP-WP sebesar, 0,1711. Terdapat perbedaan ranking pada perhitungan AHP-SAW dan AHP-WP dimana peringkat ke-2 pada AHP-SAW adalah alternatif "Tokopedia" dan peringkat ke-3 pada AHP-WP adalah alternatif "Lazada", dan sebaliknya pada AHP-WP. Hal ini disebabkan pada tata cara normalisasi yang berbeda sehingga perbedaan yang sangat tipis tersebut membuat perbedaan hasil pada perankingan. Kesimpulan dari penelitian ini menyatakan bahwa metode AHP-SAW dan AHP-WP dapat digunakan untuk menentukan E-Commerce terbaik di Indonesia.
\end{abstract}

Kata kunci: AHP, SAW, WP, E-Commerce, CRISP-DM.

\section{Comparison of AHP-SAW and AHP-WP Methods on DSS to Determine the Best E-Commerce in Indonesia}

\begin{abstract}
E-Commerce in Indonesia is predicted to grow very rapidly and become a market leader in Southeast Asia. $96 \%$ of internet users in Indonesia have used E-Commerce. The global E-Commerce industry shows a significant increase in daily web traffic of more than 50\% during the COVID-19 pandemic, due to social distancing and physical distancing by consumers. From the rampant competition, many considerations from consumers, the difficulty of choosing products make consumers still confused in choosing the right E-Commerce to make transactions. To overcome this, a decision support system (SPK) can be used to provide recommendations in choosing the right ECommerce. In this study, the method to be used is a combination of AHP-SAW and AHP-WP with the CRISP-DM framework. The best E-Commerce in Indonesia which is determined based on the weighting of the criteria from 5 active E-Commerce users as well as alternative assessments based on the 2019 eIQ Consumer Pulse survey. The results of this study state that the alternative "Bukalapak" is the best E-Commerce with the AHP-SAW preference value. amounting to 0.8543 and AHP-WP of 0.1711. There is a different ranking in the AHP-SAW and AHP-WP calculations where the 2nd rank on AHP-SAW is the "Tokopedia" alternative and the 3rd rank on the AHP-WP is the "Lazada" alternative, and vice versa on the AHP-WP. This is due to the different normalization procedures so that the very slight difference makes a difference in the results in the ranking. The conclusion of this study states that the AHP-SAW and AHP-WP methods can be used to determine the best E-Commerce in Indonesia.
\end{abstract}

Keywords: AHP, SAW, WP, E-Commerce, CRISP-DM 


\section{Pendahuluan}

E-Commerce di Indonesia diprediksi berkembang sangat pesat dan menjadi market leader di asia tenggara, mengingat $96 \%$ pengguna internet di Indonesia pernah menggunakannya[1]. Berdasarkan data tahun 2019, Indonesia memiliki nilai transaksi $E$ Commerce sebesar US\$ 21 miliar dan diprediksi bisa mencapai nilai transaksi sebesar US\$ 82 miliar di tahun 2025[2]. Kondisi terkini mengenai dampak COVID-19 terhadap industri E-Commerce secara global memperlihatkan terjadinya peningkatan signifikan terhadap traffic web harian hingga lebih dari 50\%, kemungkinan diakibatkan social distancing dan physical distancing yang dilakukan konsumen[3]. Perlindungan konsumen yang bertransaksi melalui $E$ Commerce baik secara preventif maupun represif juga telah dilindungi secara baik oleh Pemerintah[4]. Kondisi tersebut membuat E-Commerce melakukan penetrasi secara intensif untuk mendapatkan market growth di Indonesia. E-Commerce juga dituntut untuk selalu memperbaiki diri dalam memberikan produk berkualitas dan layanan prima bagi pelanggannya. Terdapat banyak E-Commerce di Indonesia, dan 6 yang terbesar di Indonesia terdiri dari Blibli, Bukalapak, JD.id, Lazada, Shopee, dan Tokopedia[5].

Dibalik kemudahan yang ditawarkan tersebut, masih terdapat pula hal negatif yang ditimbulkan seperti ketidaksesuaian produk yang dibeli, permasalahan pengiriman, keamanan metode pembayaran, hingga customer care. Dari membludaknya persaingan, banyaknya pertimbangan dari konsumen, kesulitan memilih produk yang sama namun memiliki harga yang berbeda membuat konsumen masih bingung dalam memilih $E$ Commerce yang tepat untuk melakukan transaksi. Untuk menanggulangi hal tersebut, sistem pendukung keputusan (SPK) dapat dipergunakan untuk memberikan rekomendasi dalam memilih $E$ Commerce yang tepat. SPK sendiri merupakan sebuah sistem yang efektif dalam membantu mengambil suatu keputusan yang kompleks, yang menggunakan aturan-aturan pengambilan keputusan, model analisis, basis data yang komprehensif dan pengetahuan dari pengambil keputusan[6].

Dalam penelitian ini metode yang akan digunakan adalah kombinasi dari AHP-SAW dan AHP-WP. Kombinasi metode tersebut dipilih karena AHP yang merupakan sebuah hierarki fungsional dengan input utamanya adalah persepsi manusia[7]. SAW merupakan metode sederhana yang mampu menganalisa alternatif yang ada untuk menghasilkan suatu keputusan dengan mudah[8]. Metode WP lebih efisien karena waktu yang dibutuhkan dalam perhitungan lebih singkat[9].
Pada penelitian sebelumnya, kombinasi metode tersebut dalam SPK telah diaplikasikan dengan baik dimana pengambil keputusan memberikan bobot kriteria dan sangat mempengaruhi hasil rekomendasi yang dihasilkan, dan beberapa telah berhasil diwujudkan dalam sebuah perangkat lunak[10][11]. Terkait dengan pemilihan E-Commerce, beberapa penelitian membandingkan kriteria dan alternatif berbeda dengan hasil yang baik[12][13][14][15]. Namun demikian belum ada analisis komprehensif mengenai bagaimana perbandingan antar kombinasi metode tersebut, mengambil rata-rata dari beberapa pengambil keputusan yang memiliki pembobotan berbeda, hingga bagaimana implementasinya dalam perangkat lunak.

Maka dari itu, penelitian ini bertujuan untuk dapat melakukan perhitungan secara manual dan mengimplementasikan kombinasi metode AHP-SAW dan AHP-WP dalam sebuah perangkat lunak. Urgensi dari penelitian ini apabila tidak direalisasikan akan mengakibatkan pengembangan SPK metode ini menjadi stagnan dan hanya mencapai tahap perhitungan manual dan perancangan saja, hingga dapat menghambat inovasi dibidang SPK. Berdasarkan latar belakang yang telah dipaparkan sebelumnya, maka implementasi kombinasi metode AHP-SAW dan AHP-WP pada SPK penentuan $E$ Commerce terbaik perlu untuk direalisasikan.

\section{LANDASAN TEORI}

\section{A. E-Commerce}

E-Commerce didefinisikan sebagai proses pembelian, penjualan, mentransfer atau bertukar produk, jasa atau informasi melalui jaringan komputer maupun Internet, dengan mengambil bentuk-bentuk tradisional dari proses bisnis serta memanfaatkan jejaring sosial melalui internet. Strategi bisnis dapat berhasil jika dilakukan dengan benar, yang akhirnya menghasilkan peningkatan pelanggan, kesadaran merek dan pendapatan[16]. E-Commerce dapat berjalan dengan baik berdasarkan prinsip 4C (connection, creation, consumption, control) dan dapat memotivasi konsumen yang mengarah pada return of investment (ROI) perusahaan, yang diukur dengan partisipasi aktif seperti feedback atau review konsumen, dan share atau merekomendasikan kepada pengguna lain.

Terdapat 6 platform E-Commerce teratas di Indonesia, berdasarkan tingkat frekuensi kunjungan dan peringkat aplikasi di Google Play Store yaitu Blibli, Bukalapak, JD.id, Lazada Indonesia, Shopee, dan Tokopedia[5]. Enam ECommerce tersebut secara lebih mendalam memiliki perbedaannya tersendiri. Berdasarkan survei eIQ Consumer Pulse 2019, menunjukkan konsumen yang berbelanja di situs tersebut karena memiliki alasan tertentu. Shopee, misalnya, menarik bagi orang-orang yang mencari produk mode yang terjangkau, sementara JD.id dan Blibli menarik pembeli yang mencari produk-produk Mom \& Baby atau Bahan Makanan. Hal ini menyebabkan dibalik E-Commerce yang mirip, masing-masing memiliki preferensi produk dan pembelinya tersendiri. 


\section{B. Analytical Hierarchy Process (AHP)}

Metode AHP dimanfaatkan dalam menghasilkan skala rasio berdasarkan perbandingan berpasangan berbentuk diskrit maupun kontinu dalam struktur hierarki tingkat berganda, yang memberikan manfaat dalam pengambilan keputusan dalam memilih alternatif terbaik berdasarkan kriteria tertentu[17]. Komponen utama yang dimiliki AHP merupakan suatu hierarki fungsional dengan masukan berupa persepsi manusia. Dalam metode AHP, sesuatu yang kompleks akan dipisahkan kedalam kelompokkelompok tersendiri yang kemudian kelompok tersebut disusun kedalam suatu bentuk hierarki[18]. Adapun tahapan-tahapan dalam melakukan penyelesaian permasalahan menggunakan metode AHP, yaitu decomposition (membuat hierarki), comparative judgment (penilaian kriteria dan alternatif), synthesis of priority (menentukan prioritas) dan logical consistency (konsistensi logis). Matriks perbandingan berpasangan akan diterjemahkan ke dalam skala Saaty. Skala Saaty dapat dilihat pada Tabel I.

TABEL I

SKALA SAATY

\begin{tabular}{|c|l|}
\hline $\begin{array}{c}\text { Nilai } \\
\text { Kepentingan/ } \\
\text { Intensitas }\end{array}$ & \multicolumn{1}{c|}{ Keterangan/ Linguistik } \\
\hline 1 & Sama penting (equal) \\
\hline 3 & Cukup penting (moderat) \\
\hline 5 & Lebih penting (strong) \\
\hline 7 & Sangat lebih penting (demonstrated) \\
\hline 9 & Mutlak lebih penting (extreme) \\
\hline $2,4,6,8$ & $\begin{array}{l}\text { Nilai tengah diantara nilai berdekatan } \\
\text { (intermediate value) }\end{array}$ \\
\hline
\end{tabular}

Setelah melakukan perbandingan berpasangan, dilakukan proses sintesis dengan cara sebagai berikut:

1) Menjumlahkan nilai-nilai dari setiap kolom pada matriks

2) Membagi setiap nilai dari kolom dengan total kolom yang bersangkutan untuk memperoleh normalisasi matriks.

3) Menjumlahkan nilai-nilai dari setiap baris dan membaginya dengan jumlah elemen untuk mendapatkan nilai rata-rata.

Setelah mendapatkan hasil sintesis, dilanjutkan dengan mengukur konsistensi dengan cara sebagai berikut:

1) Kalikan setiap nilai pada kolom pertama dengan prioritas relative elemen pertama, nilai pada kolom kedua dengan prioritas relative elemen kedua dan seterusnya

2) Jumlahkan setiap baris

3) Hasil dari penjumlahan baris dibagi dengan elemen prioritas relatif yang bersangkutan

4) Jumlahkan hasil bagi di atas dengan banyaknya elemen yang ada, hasilnya disebut $\lambda$ maks

Menghitung Consistency Index menggunakan formula sebagai berikut:

$C I=\frac{\left(\lambda_{\max }-n\right)}{(n-1)}$
Dimana:

$\mathrm{n}=$ banyak elemen $/$ kriteria

Menghitung Consistency Ratio menggunakan formula sebagai berikut:

$C R=\frac{C I}{I R}$

Dimana:

$\mathrm{CR}=$ Consistency Ratio

$\mathrm{CI}=$ Consistency Index

$\mathrm{IR}=$ Index Random Consistency

Index Random Consistency dalam penelitian ini menggunakan Alonso-Lamata RI Values dengan nilai yang ditampilkan pada Tabel II.

TABEL II

AlONSO-LAMATA RI VALUES

\begin{tabular}{|c|c|}
\hline Jumlah Elemen & Alonso-Lamata RI Values \\
\hline 3 & 0,5245 \\
\hline 4 & 0,8815 \\
\hline 5 & 1,1086 \\
\hline 6 & 1,2479 \\
\hline 7 & 1,3417 \\
\hline 8 & 1,4056 \\
\hline
\end{tabular}

Pemeriksaan konsistensi hirarki dilakukan dengan cara melakukan pengecekan pada hasil perhitungan Consistency Ratio. Apabila CR lebih dari 10\% maka matriks perbandingan berpasangan harus disesuaikan kembali. Apabila CR kurang dari 10\% maka konsistensi hirarki dinyatakan konsisten dan perhitungan dinyatakan benar dan dapat dilanjutkan ke tahap selanjutnya untuk perhitungan nilai preferensi dan perangkingan.

\section{Simple Addative Weigthing ( $S A W$ )}

Metode SAW sering juga dikenal istilah metode penjumlahan terbobot[8]. Metode SAW memiliki konsep dasar untuk mencari penjumlahan terbobot dari rating kinerja pada setiap alternatif pada seluruh atribut. Metode SAW membutuhkan proses normalisasi matriks keputusan $(X)$ ke suatu skala yang dapat diperbandingkan dengan semua rating alternatif. Pada penelitian ini, pembobotan telah diselesaikan dengan metode AHP, dilanjutkan dengan perhitungan perangkingan dengan metode SAW dimulai dari normalisasi alternatif pada SAW hingga mendapatkan nilai preferensi.

Nilai preferensi $\left(V_{i}\right)$ diperoleh berdasarkan penjumlahan dari perkalian elemen baris matriks ternormalisasi $(R)$ dengan bobot preferensi $(W)$ yang bersesuaian elemen kolom matriks $(W)$.

$V_{i}=\sum_{j=1}^{n} w_{j} r_{i j}$

\section{Weighted Product (WP)}

Metode WP menggunakan teknik perkalian untuk menghubungkan rating atribut, dimana rating tiap atribut harus dipangkatkan terlebih dahulu dengan bobot atribut yang bersangkutan[9]. Pada penelitian ini, pembobotan telah diselesaikan dengan metode AHP, dilanjutkan dengan perhitungan perangkingan dengan metode WP dimulai dari normalisasi alternatif pada WP hingga mendapatkan nilai 
preferensi. Nilai vector $(S)$ didapatkan dengan mengalikan seluruh kriteria dengan alternatif hasil normalisasi/perbaikan bobot yang berpangkat positif untuk kriteria keuntungan dan yang berpangkat negatif untuk kriteria biaya. Hasil akhir nilai preferensi $\left(V_{i}\right)$ diperoleh dari jumlah nilai vektor $(S)$ dengan jumlah seluruh nilai vektor $(S)$

$$
V_{i}=\frac{\prod_{j=1}^{n} x_{i j} w_{j}}{\sum\left(\prod_{j=1}^{n} x_{i j} w_{j}\right)}
$$

\section{E. Cross-Industry Standard Process for Data mining (CRISP-DM)}

CRISP-DM adalah de facto standar untuk pengembangan proyek data mining dan knowledge discovery karena paling banyak digunakan dalam pengembangan data mining[19]. Model referensi CRISPDM memberikan gambaran umum dari siklus hidup proyek data mining, dapat dipecah menjadi enam fase yaitu Business Understanding, Data Understanding, Data Preparation, Modeling, Evaluation dan Deployment[20]. Fase model CRISP-DM dapat dilihat pada Error! Reference source not found.

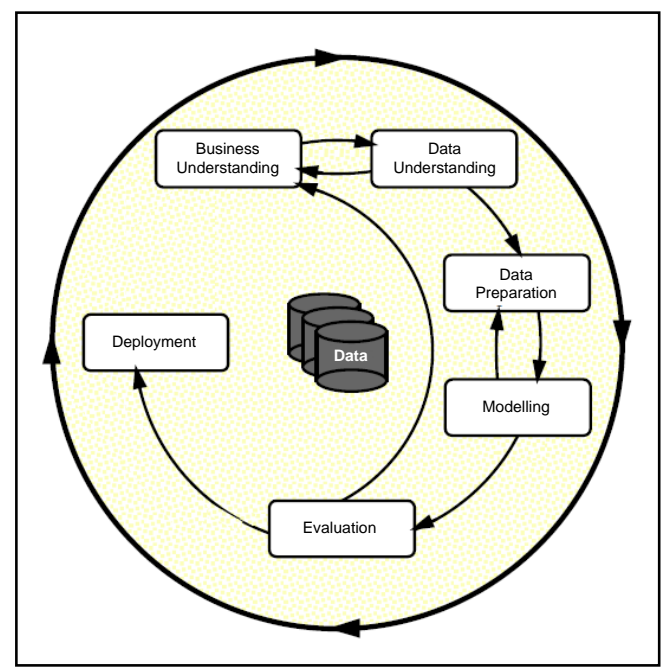

Gambar. 1 Fase model proses terkini terkait CRISP-DM

\section{Metode Penelitian}

Metode penelitian yang digunakan dalam penelitian ini mengikuti tahapan model CRISP-DM[21]. Permasalahan yang berkaitan dengan data seperti data mining dan SPK dapat menggunakan metode CRISP-DM yang diharapkan mampu untuk menganalisis permasalahan bisnis dan kondisi yang sedang terjadi, memberikan transformasi data yang sesuai hingga memberikan model yang dapat menilai efektivitas dan mendokumentasikan hasil yang didapatkan. CRISP-DM memecahkan permasalahan tersebut dengan mendefinisikan model proses yang berkaitan dengan data mining dan SPK terlepas dari apapun sektor permasalahan ataupun teknologi yang digunakan.

\section{A. Business Understanding}

Business understanding adalah tahap yang digunakan untuk menentukan tujuan bisnis, melakukan analisis situasi bisnis, hingga penentuan tujuan dari SPK. Pada tahap ini dilakukan pemahaman yang menyeluruh berdasarkan analisis dari hasil observasi, wawancara dan dokumendokumen yang mendukung tujuan dan hasil penelitian. Dalam menentukan E-Commerce terbaik di Indonesia, ditemukan beberapa alternatif yang dapat dipetakan. Berdasarkan alternatif tersebut akan dilakukan perhitungan untuk melakukan perankingan. Hasil dari E-Commerce terbaik dapat menjadi pilihan terbaik bagi konsumen untuk melakukan transaksi digital. Di lain sisi, E-Commerce yang belum mencapai hasil optimal masih dapat meningkatkan kinerjanya agar mendapatkan market share yang lebih baik. Dalam menentukan jumlah alternatif dan kriteria-kriteria dari calon E-Commerce terbaik, merujuk pada penilaian dalam survei eIQ Consumer Pulse 2019, menghasilkan 6 alternatif yaitu Blibli, Bukalapak, JD.id, Lazada Indonesia, Shopee, dan Tokopedia. Narasumber yang akan digunakan adalah netizen yang pernah menggunakan E-Commerce sebanyak 5 orang. Pembobotan kriteria didapatkan dari narasumber dan dihitung menggunakan AHP dan penilaian terhadap alternatif menggunakan metode SAW dan WP.

\section{B. Data Understanding}

Pada tahap ini dilakukan proses pengumpulan data, kemudian melakukan analisa data serta melakukan evaluasi kualitas data yang digunakan dalam penelitian. Untuk dapat menggunakan metode AHP-SAW dan AHP-WP dengan baik, perlu mendapatkan data kriteria dan alternatif yang sesuai. Kriteria yang digunakan dalam penelitian ini meliputi: (C1) Reputasi, (C2) Harga, (C3) Produk, (C4) Customer Care, (C5) Pengiriman, (C6) UX Apps, (C7) Pembayaran dan (C8) Keamanan \& Kebijakan. Reputasi merupakan nama baik dari E-Commerce di masyarakat. Harga adalah nominal yang harus dibayarkan konsumen dan seberapa murah dibandingkan dengan E-Commerce pesaing. Produk meliputi ragam produk, keaslian produk, pemilihan produk, dan kualitas produk. Customer care merupakan pelayanan customer service yang baik. Pengiriman meliputi kecepatan pengiriman, kondisi free delivery, dan waktu yang dipergunakan untuk memproses pengiriman. UX Apps meliputi kemudahan penggunaan aplikasi, mobile apps, dan $U X$ yang menyenangkan konsumen. Pembayaran meliputi ragam cara pembayaran, proses pembayaran, dan kualitas masing-masing ragam cara pembayaran. Keamanan \& Kebijakan meliputi retur barang, loyalty program, promosi dan keamanan.

\section{Data Preparation}

Dalam tahapan ini meliputi pemilihan data yang akan digunakan dan data yang akan dikeluarkan untuk dimasukkan dalam perhitungan SPK. Dalam tahap ini juga dilakukan data cleaning untuk memperbaiki, menghapus atau mengabaikan noise pada data.

\section{Modeling}

Pada tahap business understanding telah dipilih tools, teknik ataupun metode yang akan digunakan dalam penelitian ini. Metode AHP-SAW dan AHP-WP dipilih untuk menentukan E-Commerce terbaik di Indonesia. Sebelum melanjutkan penelitian dapat melakukan test design dengan data sementara untuk membuktikan metode 
tersebut dapat digunakan. Flowchart penggunaan metode dapat dilihat pada Gambar 2.

Tahap pertama adalah persiapan data perbandingan antar kriteria yang bersumber dari decision maker sebagai narasumber, dan data alternatif yang berasal dari data $E$ Commerce di Indonesia berdasarkan survei eIQ Consumer Pulse 2019. Metode AHP digunakan untuk menentukan data pembobotan kriteria, dimulai dari menentukan matriks perbandingan berpasangan, melakukan normalisasi, menghitung eigen vector dan mengecek konsistensi hirarki. Selanjutnya, data alternatif dilakukan normalisasi menggunakan metode SAW dan metode WP sehingga menghasilkan data normalisasi alternatif. Data pembobotan kriteria menggunakan metode AHP dan data normalisasi alternatif menggunakan metode SAW dan metode WP akan dilakukan perhitungan normalisasi terbobot dan menghitung nilai preferensi dan akan menghasilkan nilai preferensi yang dapat dilakukan perangkingan untuk dapat menentukan E-Commerce terbaik yang dapat menjadi referensi pilihan dari pelangan ataupun masukan sebagai perbaikan bagi E-Commerce yang masih memiliki kekurangan di beberapa segmen.

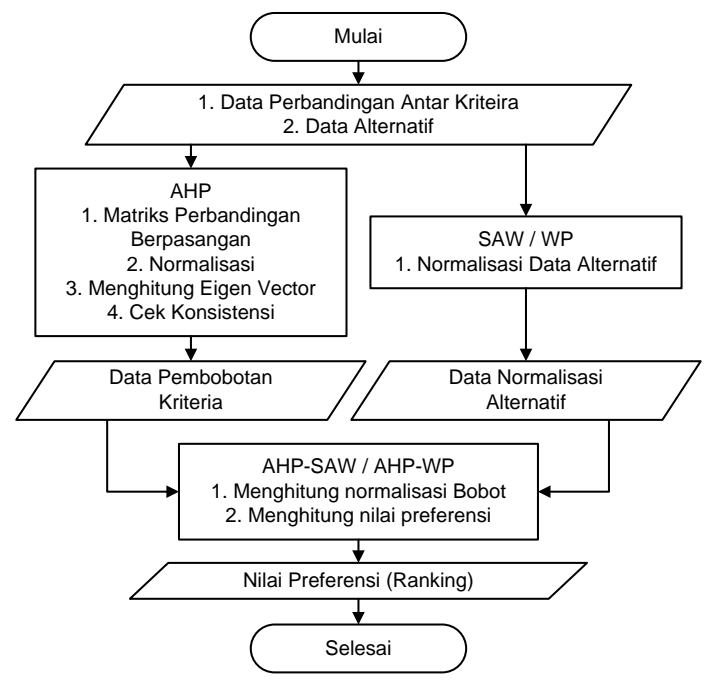

Gambar. 2 Flowchart penggunaan metode AHP-SAW dan AHP-WP

\section{E. Evaluation}

Pada tahap ini dilakukan pengujian baik pada hasil rekomendasi dari SPK maupun kinerja dari metode yang dipergunakan. Perlu adanya pengecekan terhadap perhitungan secara manual dan hasil yang didapatkan ketika diimplementasikan pada perangkat lunak yang dihasilkan memiliki nilai yang sama agar terdapat kesesuaian antar keduanya. Uji sensitivitas digunakan untuk membandingkan kinerja antara metode SAW dan WP untuk mengukur metode mana yang lebih sensitif terhadap perubahan pembobotan kriteria, sehingga metode yang lebih sensitif merupakan metode yang lebih baik.

\section{F. Deployment}

Pada tahap ini dilakukan perencanaan deployment berdasarkan evaluasi yang telah dilakukan sebelumnya. Apabila hasil uji menunjukkan hasil yang baik, maka dapat direncakan deployment selanjutnya. Selain merencanakan deployment juga dapat direncanakan mengenai rencana monitoring dan maintenance hingga menghasilkan final report terkait hasil penelitian

\section{HASIL DAN PEMBAHASAN}

Penelitian ini dilakukan berdasarkan data kuisioner dari pengguna yang telah paham dengan baik mengenai $E$ Commerce, yang ditransformasikan dalam metode AHP sebagai perbandingan antar kriteria dan data E-Commerce digunakan sebagai data alternatif. Jumlah narasumber yang digunakan untuk melakukan perbandingan antar kriteria untuk menghasilkan pembobotan kriteria sebanyak 5 orang, dan jumlah data E-Commerce yang digunakan adalah 6 perusahaan.

Perhitungan dimulai dengan menggunakan metode AHP. Terdapat 8 kriteria yaitu (C1) Reputasi, (C2) Harga, (C3) Produk, (C4) Customer Care, (C5) Pengiriman, (C6) UX Apps, (C7) Pembayaran dan (C8) Keamanan \& Kebijakan. Pembobotan dari Narasumber 1, Narasumber 2, Narasumber 3, Narasumber 4 dan Narasumber 5, masingmasing ditampilkan pada Tabel III, sampai tabel VII. Pembobotan dengan nilai sama penting (equal) tidak ditampilkan dalam tabel.

TABEL III

MATRIKS PERBANDINGAN BERPASANGAN NARASUMBER

\begin{tabular}{|c|c|c|c|c|c|c|c|c|}
\hline Kriteria & C1 & C2 & C3 & C4 & C5 & C6 & C7 & C8 \\
\hline C1 & - & & & & & & MD & \\
\hline C2 & ST & - & MD & MD & & MD & MD & \\
\hline C3 & & & - & MD & & & & \\
\hline C4 & & & & - & & & & \\
\hline C5 & MD & & & & - & MD & MD & \\
\hline C6 & & & & & & - & & \\
\hline C7 & & & & & & & - & \\
\hline C8 & ST & MD & MD & MD & MD & & MD & - \\
\hline
\end{tabular}

TABEL IV

MATRIKS PERBANDINGAN BERPASANGAN NARASUMBER 2

\begin{tabular}{|c|c|c|c|c|c|c|c|c|}
\hline Kriteria & C1 & C2 & C3 & C4 & C5 & C6 & C7 & C8 \\
\hline C1 & - & & MD & & & & & \\
\hline C2 & & - & MD & MD & MD & ST & & \\
\hline C3 & & & - & & & MD & & \\
\hline C4 & MD & & & - & & & & \\
\hline C5 & MD & & & & - & & & \\
\hline C6 & & & & & & - & & \\
\hline C7 & & & & & & & - & \\
\hline C8 & ST & MD & ST & MD & MD & ST & ST & - \\
\hline
\end{tabular}

TABEL V

MATRIKS PERBANDINGAN BERPASANGAN NARASUMBER 3

\begin{tabular}{|c|c|c|c|c|c|c|c|c|}
\hline Kriteria & C1 & C2 & C3 & C4 & C5 & C6 & C7 & C8 \\
\hline C1 & - & & & & & & & \\
\hline C2 & DM & - & MD & ST & ST & ST & ST & ST \\
\hline C3 & & & - & MD & MD & MD & & \\
\hline C4 & & & & - & & & & \\
\hline C5 & & & & & - & & & \\
\hline C6 & & & & MD & & - & & \\
\hline C7 & & & MD & MD & & & - & \\
\hline C8 & & & MD & ST & MD & MD & MD & - \\
\hline
\end{tabular}


TABEL VI

MATRIKS PERBANDINGAN BERPASANGAN NARASUMBER 4

\begin{tabular}{|c|c|c|c|c|c|c|c|c|}
\hline Kriteria & C1 & C2 & C3 & C4 & C5 & C6 & C7 & C8 \\
\hline C1 & - & & & MD & & & & \\
\hline C2 & MD & - & MD & MD & MD & MD & MD & MD \\
\hline C3 & DM & & - & & & & & \\
\hline C4 & & & & - & & & & \\
\hline C5 & & & & & - & & & \\
\hline C6 & & & & & & - & & \\
\hline C7 & & & & & & & - & \\
\hline C8 & MD & & MD & & & & & - \\
\hline
\end{tabular}

TABEL VII

MATRIKS PERBANDINGAN BERPASANGAN NARASUMBER 5

\begin{tabular}{|c|c|c|c|c|c|c|c|c|}
\hline Kriteria & C1 & C2 & C3 & C4 & C5 & C6 & C7 & C8 \\
\hline C1 & - & & & & & & & \\
\hline C2 & MD & - & MD & MD & & & & \\
\hline C3 & & & - & & & & & \\
\hline C4 & & & & - & & & & \\
\hline C5 & & & & & - & & & \\
\hline C6 & ST & ST & MD & MD & & - & MD & ST \\
\hline C7 & MD & & & MD & & & - & \\
\hline C8 & & & MD & & MD & & & - \\
\hline
\end{tabular}

Keterangan:

EQ : Sama Penting (Equal)

MD : Cukup Penting (Moderat)

ST : Lebih Penting (Strong)

DM : Sangat Lebih Penting (Demonstrated)

EX : Mutlak Lebih Penting (Extreme)

Selanjutnya akan berfokus pada Narasumber 1, dimana narasumber lainnya memiliki langkah perhitungan yang sama. Matriks perbandingan kriteria pada Narasumber 1 diterjemahkan berdasarkan skala Saaty Hasil transformasi matriks perbandingan berpasangan disajikan pada Tabel VIII.

TABEL VIII

MATRIKS PERBANDINGAN BERPASANGAN NARASUMBER 1 DITERJEMAHKAN DENGAN SKALA SAATY

\begin{tabular}{|c|c|c|c|c|c|c|c|c|}
\hline Kriteria & C1 & C2 & C3 & C4 & C5 & C6 & C7 & C8 \\
\hline C1 & 1 & $1 / 5$ & 1 & 1 & $1 / 3$ & 1 & 3 & $1 / 5$ \\
\hline C2 & 5 & 1 & 3 & 3 & 1 & 3 & 3 & $1 / 3$ \\
\hline C3 & 1 & $1 / 3$ & 1 & 3 & 1 & 1 & 1 & $1 / 3$ \\
\hline C4 & 1 & $1 / 3$ & $1 / 3$ & 1 & 1 & 1 & 1 & $1 / 3$ \\
\hline C5 & 3 & 1 & 1 & 1 & 1 & 3 & 3 & $1 / 3$ \\
\hline C6 & 1 & $1 / 3$ & 1 & 1 & $1 / 3$ & 1 & 1 & 1 \\
\hline C7 & $1 / 3$ & $1 / 3$ & 1 & 1 & $1 / 3$ & 1 & 1 & $1 / 3$ \\
\hline C8 & 5 & 3 & 3 & 3 & 3 & 1 & 3 & 1 \\
\hline SUM & 17 & 6 & 11 & \multirow{2}{*}{14} & 8 & 12 & \multirow{2}{*}{16} & 3 \\
& $1 / 3$ & $1 / 2$ & $1 / 3$ & & & & \\
\hline
\end{tabular}

Normalisasi dalam metode AHP dilakukan dengan cara membagi nilai elemen dengan jumlah nilai kolomnya, dan nilai eigen vector dihasilkan dari penjumlahan kriteria setiap barisnya, sebagai berikut:

$$
\begin{aligned}
& C_{11}=\frac{1}{17^{1 / 3}}=0,058 \\
& C_{13}=\frac{1}{11^{1 / 3}}=0,088 \\
& C_{15}=\frac{1 / 3}{8}=0,042 \\
& C_{17}=\frac{3}{16}=0,188
\end{aligned}
$$

$$
\begin{aligned}
& C_{12}=\frac{1 / 5}{6^{1} / 2}=0,031 \\
& C_{14}=\frac{1}{14}=0,071 \\
& C_{16}=\frac{1}{12}=0,083 \\
& C_{18}=\frac{1 / 5}{3^{7} / 8}=0,052
\end{aligned}
$$

$E V C_{1}=\frac{0,058+0,031+0,088+0,071+0,042+0,083+0,188+0,052}{8}=$ $\frac{0,612}{8}=0,0766$

Untuk kriteria selanjutnya menggunakan formula yang sama sehingga menghasilkan nilai eigen vector yang ditampilkan pada tabel IX, sebagai berikut:

TABEL IX

EIGEN VECTOR KRITERIA OLEH NARASUMBER 1

\begin{tabular}{|c|l|c|}
\hline Kode Kriteria & \multicolumn{1}{|c|}{ Kriteria } & Eigen Vector \\
\hline C1 & Reputasi & 0,0766 \\
\hline C2 & Harga & 0,1961 \\
\hline C3 & Produk & 0,0960 \\
\hline C4 & Customer Care & 0,0708 \\
\hline C5 & Pengiriman & 0,1418 \\
\hline C6 & UX \& Apps & 0,0894 \\
\hline C7 & Pembayaran & 0,0629 \\
\hline C 8 & Keamanan \& Kebijakan & 0,2664 \\
\hline
\end{tabular}

Setelah mendapatkan Eigen Vector dari masing-masing kriteria, selanjutnya dapat dihitung $\lambda_{\max }$, dimulai dari mengalikan matriks perbandingan berpasangan dengan eigen vector. Masing-masing hasilnya perkalian tersebut, dibagi kembali dengan eigen vector, dan dicari rata-ratanya hingga mendapatkan $\lambda_{\max } . \lambda_{\max }$ untuk narasumber 1 , ditentukan dengan menggunakan langkah-langkah berikut ini:

$$
\begin{aligned}
& \lambda=\left[\begin{array}{llllllll}
1,0 & 0,2 & 1,0 & 1,0 & 0,3 & 1,0 & 3,0 & 0,2 \\
5,0 & 1,0 & 3,0 & 3,0 & 1,0 & 3,0 & 3,0 & 0,3 \\
1,0 & 0,3 & 1,0 & 3,0 & 1,0 & 1,0 & 1,0 & 0,3 \\
1,0 & 0,3 & 0,3 & 1,0 & 1,0 & 1,0 & 1,0 & 0,3 \\
3,0 & 1,0 & 1,0 & 1,0 & 1,0 & 3,0 & 3,0 & 0,3 \\
1,0 & 0,3 & 1,0 & 1,0 & 0,3 & 1,0 & 1,0 & 1,0 \\
0,3 & 0,3 & 1,0 & 1,0 & 0,3 & 1,0 & 1,0 & 0,3 \\
5,0 & 3,0 & 3,0 & 3,0 & 3,0 & 1,0 & 3,0 & 1,0
\end{array}\right]\left[\begin{array}{l}
0,0766 \\
0,1961 \\
0,0960 \\
0,0708 \\
0,1418 \\
0,0894 \\
0,0629 \\
0,2664
\end{array}\right]=\left[\begin{array}{l}
0,6611 \\
1,7668 \\
0,8330 \\
0,6275 \\
1,2800 \\
0,7746 \\
0,5460 \\
2,4414
\end{array}\right] \\
& \lambda_{\max }=\left(\frac{0,6611}{0,0766}+\frac{1,7668}{0,1961}+\frac{0,8330}{0,0960}+\frac{0,6275}{0,0708}+\frac{1,2800}{0,1418}+\right. \\
& \left.\quad \frac{0,7746}{0,0894}+\frac{0,5460}{0,0629}+\frac{2,4414}{0,2664}\right) / 8 \\
& \lambda_{\max }= \\
& \quad \frac{(8,6277+9,0085+8,6771+8,8693+9,03+8,6669+8,6839+9,1653)}{8} \\
& \lambda_{\max }=8,8411
\end{aligned}
$$

Setelah mendapatkan $\lambda_{\max }$ selanjutnya dapat menghitung Consistency Index untuk narasumber 1, menggunakan langkah-langkah sebagai berikut:

$C I=\frac{\left(\lambda_{\max }-n\right)}{(n-1)}=\frac{(8,8411-8)}{(8-1)}=\frac{0,8411}{7}=0,1202$

Setelah mendapatkan CI, selanjutnya dapat menghitung Consistency Ratio untuk narasumber 1. Berdasarkan Alonso-lamata RI Values, maka IR yang digunakan adalah 1,4056 mengingat jumlah kriteria adalah 8. CR dapat dihitung menggunakan langkah-langkah sebagai berikut: $C R=\frac{C I}{I R}=\frac{0,1202}{1,4056}=0,0855$

Karena CR kurang dari 0,1 maka hirarki dinilai konsisten, perhitungan dinyatakan benar dan dapat digunakan sebagai bobot kriteria. Matriks perbandingan Narasumber 2, Narasumber 3, Narasumber 4, dan Narasumber 5 juga dihitung menggunakan langkahlangkah yang sama dengan Narasumber 1, sehingga 
menghasilkan nilai eigen vector untuk seluruh narasumber. Untuk mencari rata-rata pembobotan dari seluruh narasumber, akan dilakukan perhitungan geometric mean (GEOMEAN) dari bobot kriteria seluruh narasumber. Apabila jumlah dari bobot kriteria dari GEOMEAN tidak sama dengan 1, maka dilakukan normalisasi terhadap bobot kriteria tersebut. Langkah-langkah untuk mendapatkan pembobotan kriteria rata-rata adalah sebagai berikut:

TABEL X

Pembobotan Kriteria Oleh Kelima NARASUmber, BESERTA GEOMERTRIC MEAN (GEOMEAN)

\begin{tabular}{|c|c|c|c|c|c|c|}
\hline $\begin{array}{c}\text { Krite- } \\
\text { ria }\end{array}$ & $\begin{array}{c}\text { EV } \\
\text { N1 }\end{array}$ & $\begin{array}{c}\text { EV } \\
\text { N2 }\end{array}$ & $\begin{array}{c}\text { EV } \\
\text { N3 }\end{array}$ & $\begin{array}{c}\text { EV } \\
\text { N4 }\end{array}$ & $\begin{array}{c}\text { EV } \\
\text { N5 }\end{array}$ & $\begin{array}{c}\text { Geo- } \\
\text { Mean }\end{array}$ \\
\hline C1 & 0,077 & 0,084 & 0,073 & 0,095 & 0,066 & 0,0781 \\
\hline C2 & 0,196 & 0,176 & 0,375 & 0,280 & 0,135 & 0,2178 \\
\hline C3 & 0,096 & 0,079 & 0,109 & 0,127 & 0,072 & 0,0946 \\
\hline C4 & 0,071 & 0,093 & 0,045 & 0,088 & 0,070 & 0,0712 \\
\hline C5 & 0,142 & 0,093 & 0,059 & 0,093 & 0,104 & 0,0944 \\
\hline C6 & 0,089 & 0,063 & 0,070 & 0,093 & 0,304 & 0,1022 \\
\hline C7 & 0,063 & 0,082 & 0,098 & 0,093 & 0,122 & 0,0895 \\
\hline C8 & 0,266 & 0,331 & 0,171 & 0,130 & 0,127 & 0,1901 \\
\hline SUM & 1,000 & 1,000 & 1,000 & 1,000 & 1,000 & 0,9380 \\
\hline
\end{tabular}

$$
\begin{aligned}
w_{i}{ }^{*}=\frac{w_{i}}{\sum w} & \\
w_{1}{ }^{*}=\frac{0,0781}{0,9380}=0,0833 & w_{2}{ }^{*}=\frac{0,2178}{0,9380}=0,2322 \\
w_{3}{ }^{*}=\frac{0,0946}{0,9380}=0,1009 & w_{4}{ }^{*}=\frac{0,0712}{0,9380}=0,0760 \\
w_{5}{ }^{*}=\frac{0,0944}{0,9380}=0,1006 & w_{6}{ }^{*}=\frac{0,1022}{0,9380}=0,1090 \\
w_{7}{ }^{*}=\frac{0,0895}{0,9380}=0,0954 & w_{8}{ }^{*}=\frac{0,1901}{0,9380}=0,2027
\end{aligned}
$$

Setelah mendapatkan hasil pembobotan kriteria, dilanjutkan dengan menghitung nilai alternatif menggunakan metode SAW dan metode WP. Perhitungan dengan metode $\mathrm{SAW}$, dimulai dari perhitungan normalisasi alternatif, menghitung nilai preferensi dan melakukan perangkingan. Data $E$-Commerce tersebut terdiri dari Blibli (A1), Bukalapak (A2), JD.ID (A3), Lazada (A4), Shoopee (A5), dan Tokopedia(A6). Berdasarkan data E-Commerce yang telah ditentukan sebelumnya, menghasilkan data yang ditampilkan pada tabel XI, sebagai berikut:

TABEL XI

DATA ALTERNATIF E-COMMERCE

\begin{tabular}{|l|l|l|l|l|l|l|l|l|}
\hline $\begin{array}{c}\text { Alter- } \\
\text { natif }\end{array}$ & C1 & C2 & C3 & C4 & C5 & C6 & C7 & C8 \\
\hline A1 & 14,8 & 29,9 & 138,6 & 18,4 & 48,1 & 19,8 & 13,6 & 15,0 \\
\hline A2 & 13,0 & 21,9 & 141,8 & 23,3 & 32,7 & 32,4 & 13,7 & 21,4 \\
\hline A3 & 12,9 & 26,4 & 143,7 & 8,3 & 54,2 & 22,8 & 17,2 & 13,7 \\
\hline A4 & 13,7 & 23,5 & 143,0 & 15,8 & 46,2 & 19,5 & 16,1 & 22,2 \\
\hline A5 & 10,9 & 23,6 & 144,6 & 18,7 & 48,4 & 23,0 & 9,9 & 22,4 \\
\hline A6 & 14,3 & 21,7 & 145,5 & 21,4 & 30,7 & 31,6 & 12,2 & 22,7 \\
\hline MIN & 10,9 & 21,7 & 138,6 & 8,3 & 30,7 & 19,5 & 9,9 & 13,7 \\
\hline MAX & 14,8 & 29,9 & 145,5 & 23,3 & 54,2 & 32,4 & 17,2 & 22,7 \\
\hline
\end{tabular}

Berdasarkan data alternatif tersebut, dapat dihitung normalisasi alternatifnya menggunakan metode SAW. Normalisasi metode SAW pada kondisi benefit, dilakukan dengan cara membagi nilai kriteria dengan nilai maksimum kriteria pada kolomnya. Contoh normalisasi pada alternatif 1, ditampilkan pada perhitungan sebagai berikut:

$$
\begin{array}{ll}
r_{11}=\frac{14,8}{14,8}=1 ; & r_{12}=\frac{29,9}{29,9}=1 ; \\
r_{13}=\frac{138,6}{145,5}=0,953 ; & r_{14}=\frac{18,4}{23,3}=0,790 ; \\
r_{15}=\frac{48,1}{54,2}=0,887 ; & r_{16}=\frac{19,8}{32,4}=0,611 ; \\
r_{17}=\frac{13,6}{17,2}=0,791 ; & r_{18}=\frac{15,0}{22,7}=0,661 ;
\end{array}
$$

Untuk alternatif selanjutnya menggunakan formula yang sama sehingga menghasilkan nilai normalisasi alternatif yang ditampilkan pada tabel XII, sebagai berikut:

TABEL XII

Data Normalisasi Alternatif MENGgunaKan Metode SAW

\begin{tabular}{|c|c|c|c|c|c|c|c|c|}
\hline $\begin{array}{c}\text { Alter- } \\
\text { natif }\end{array}$ & C1 & C2 & C3 & C4 & C5 & C6 & C7 & C8 \\
\hline A1 & 1,00 & 1,00 & 0,95 & 0,79 & 0,89 & 0,61 & 0,79 & 0,66 \\
\hline A2 & 0,88 & 0,73 & 0,97 & 1,00 & 0,60 & 1,00 & 0,80 & 0,94 \\
\hline A3 & 0,87 & 0,88 & 0,99 & 0,36 & 1,00 & 0,70 & 1,00 & 0,60 \\
\hline A4 & 0,93 & 0,79 & 0,98 & 0,68 & 0,85 & 0,60 & 0,94 & 0,98 \\
\hline A5 & 0,74 & 0,79 & 0,99 & 0,80 & 0,89 & 0,71 & 0,58 & 0,99 \\
\hline A6 & 0,97 & 0,73 & 1,00 & 0,92 & 0,57 & 0,98 & 0,71 & 1,00 \\
\hline
\end{tabular}

Setelah mendapatkan nilai normalisasi alternatif, dilanjutkan dengan perhitungan nilai preferensi, dengan cara menjumlahkan seluruh normalisasi alternatif terbobot, dimana bobot kriteria dihasilkan pada metode AHP dengan nilai normalisasi alternatif pada metode SAW. Contoh perhitungan nilai preferensi menggunakan AHP-SAW pada alternatif 1 , ditampilkan pada perhitungan sebagai berikut:

$$
V_{i}=\sum_{j=1}^{n} w_{j} r_{i j}
$$

$V_{1}=\sum[(0,083 \times 1,0) ;(0,232 \times 1,0) ;(0,101 \times$

$0,95) ;(0,076 \times 0,79) ;(0,101 \times 0,89) ;(0,109 \times$

$0,61) ;(0,095 \times 0,79) ;(0,203 \times 0,66)$

$V_{1}=$

$\sum(0,083 ; 0,232 ; 0,096 ; 0,060 ; 0,089 ; 0,067 ; 0,075 ; 0,134)$ $V_{1}=0,8369$

Untuk alternatif selanjutnya menggunakan formula yang sama sehingga menghasilkan nilai preferensi dan perangkingan yang ditampilkan pada tabel XIII, sebagai berikut:

TABEL XIII

Nilai Preferensi dan Perangkingan MENGgunaKan AHP-SAW

\begin{tabular}{|l|l|l|c|}
\hline No & Alternatif & Nilai Preferensi & Peringkat \\
\hline 1 & Blibli & 0,8369 & Peringkat ke-4 \\
\hline 2 & Bukalapak & 0,8543 & Peringkat ke-1 \\
\hline 3 & JD.ID & 0,7994 & Peringkat ke-6 \\
\hline 4 & Lazada & 0,8492 & Peringkat ke-3 \\
\hline 5 & Shoopee & 0,8280 & Peringkat ke-5 \\
\hline 6 & Tokopedia & 0,8534 & Peringkat ke-2 \\
\hline
\end{tabular}

Selanjutnya untuk mencari nilai preferensi menggunakan metode WP, dilakukan perhitungan normalisasi alternatif untuk mencari nilai vector (S), menghitung nilai preferensi dan perangkingan. Berdasarkan data alternatif yang telah ditentukan sebelumnya, nilai vector menggunakan metode WP pada kondisi benefit, dilakukan dengan cara memangkatkan nilai 
alternatif dengan pembobotan antar kriteria yang dihasilkan pada metode AHP. Contoh perhitungan nilai vector pada alternatif 1 , ditampilkan pada perhitungan sebagai berikut:

$S_{11}=14,8^{(0,083)}=1,251 ; \quad S_{12}=29,9^{(0,232)}=2,201$

$S_{13}=138,6^{(0,101)}=1,645 ; \quad S_{14}=18,4^{(0,076)}=1,248$

$S_{15}=48,1^{(0,101)}=1,477 ; \quad S_{16}=19,8^{(0,109)}=1,385$

$S_{17}=13,6^{(0,095)}=1,283 ; \quad S_{18}=15,0^{(0,203)}=1,731$

Untuk alternatif selanjutnya menggunakan formula yang sama sehingga menghasilkan nilai normalisasi alternatif yang ditampilkan pada tabel XIV, sebagai berikut:

TABEL XIV

Data NiLAi VECTOR MENGGUNAKAN METODE WP

\begin{tabular}{|l|c|c|c|c|c|c|c|c|}
\hline $\begin{array}{c}\text { Alter- } \\
\text { natif }\end{array}$ & C1 & C2 & C3 & C4 & C5 & C6 & C7 & C8 \\
\hline A1 & 1,25 & 2,20 & 1,64 & 1,25 & 1,48 & 1,38 & 1,28 & 1,73 \\
\hline A2 & 1,24 & 2,05 & 1,65 & 1,27 & 1,42 & 1,46 & 1,28 & 1,86 \\
\hline A3 & 1,24 & 2,14 & 1,65 & 1,17 & 1,49 & 1,41 & 1,31 & 1,70 \\
\hline A4 & 1,24 & 2,08 & 1,65 & 1,23 & 1,47 & 1,38 & 1,30 & 1,87 \\
\hline A5 & 1,22 & 2,08 & 1,65 & 1,25 & 1,48 & 1,41 & 1,24 & 1,88 \\
\hline A6 & 1,25 & 2,04 & 1,65 & 1,26 & 1,41 & 1,46 & 1,27 & 1,88 \\
\hline
\end{tabular}

Setelah mendapatkan nilai vector, dilanjutkan dengan perhitungan nilai preferensi, dengan cara mengalikan seluruh nilai vector alternatif, dan dibagi dengan jumlah seluruh nilai vector. Perhitungan nilai preferensi menggunakan AHP-WP ditampilkan pada perhitungan sebagai berikut:

$$
\begin{aligned}
S_{1}= & 1,251 \times 2,201 \times 1,645 \times 1,248 \times 1,477 \times 1,385 \times \\
& 1,283 \times 1,731=25,664 \\
S_{2}= & 1,238 \times 2,047 \times 1,648 \times 1,270 \times 1,420 \times 1,461 \times \\
& 1,284 \times 1,861=26,306 \\
S_{3}= & 1,237 \times 2,138 \times 1,651 \times 1,174 \times 1,494 \times 1,406 \times \\
& 1,312 \times 1,700=24,031 \\
S_{4}= & 1,243 \times 2,081 \times 1,650 \times 1,233 \times 1,471 \times 1,382 \times \\
& 1,304 \times 1,874=26,158 \\
S_{5}= & 1,220 \times 2,083 \times 1,652 \times 1,249 \times 1,477 \times 1,407 \times \\
& 1,245 \times 1,878=25,486 \\
S_{6}= & 1,248 \times 2,043 \times 1,653 \times 1,262 \times 1,411 \times 1,457 \times \\
& 1,270 \times 1,883=26,142 \\
S= & \sum(25,664 ; 26,306 ; 24,031 ; 26,158 ; 25,486 ; 26,142) \\
S= & 153,787
\end{aligned}
$$

$V_{1}=\frac{25,664}{153,787}=0,1669 ;$

$V_{3}=\frac{24,031}{153,787}=0,1563$;

$V_{5}=\frac{25,486}{153,787}=0,1657$;

$$
\begin{aligned}
& V_{2}=\frac{26,306}{153,787}=0,1711 ; \\
& V_{4}=\frac{26,158}{153,787}=0,1701 ; \\
& V_{6}=\frac{26,142}{153,787}=0,1700 ;
\end{aligned}
$$

Hasil dari nilai preferensi dan perangkingan menggunakan AHP-WP ditampilkan pada tabel XV, sebagai berikut:

TABEL XV

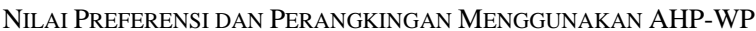

\begin{tabular}{|l|l|l|c|}
\hline No & Alternatif & Nilai Preferensi & Peringkat \\
\hline 1 & Blibli & 0,1669 & Peringkat ke-4 \\
\hline 2 & Bukalapak & 0,1711 & Peringkat ke-1 \\
\hline 3 & JD.ID & 0,1563 & Peringkat ke-6 \\
\hline
\end{tabular}

\begin{tabular}{|l|l|l|c|}
\hline No & Alternatif & Nilai Preferensi & Peringkat \\
\hline 4 & Lazada & 0,1701 & Peringkat ke-2 \\
\hline 5 & Shoopee & 0,1657 & Peringkat ke-5 \\
\hline 6 & Tokopedia & 0,1700 & Peringkat ke-3 \\
\hline
\end{tabular}

Hasil perhitungan manual pada perhitungan menggunakan AHP-SAW dan AHP-WP tersebut juga diimplementasikan ke dalam sebuah perangkat lunak berbasis web, dengan hasil yang bersesuaian dengan perhitungan manual yang telah dilakukan sebelumnya yang menggunakan microsoft excel. Implementasi pembobotan berpasangan menggunakan AHP oleh narasumber 1 dapat dilihat pada gambar 3 .

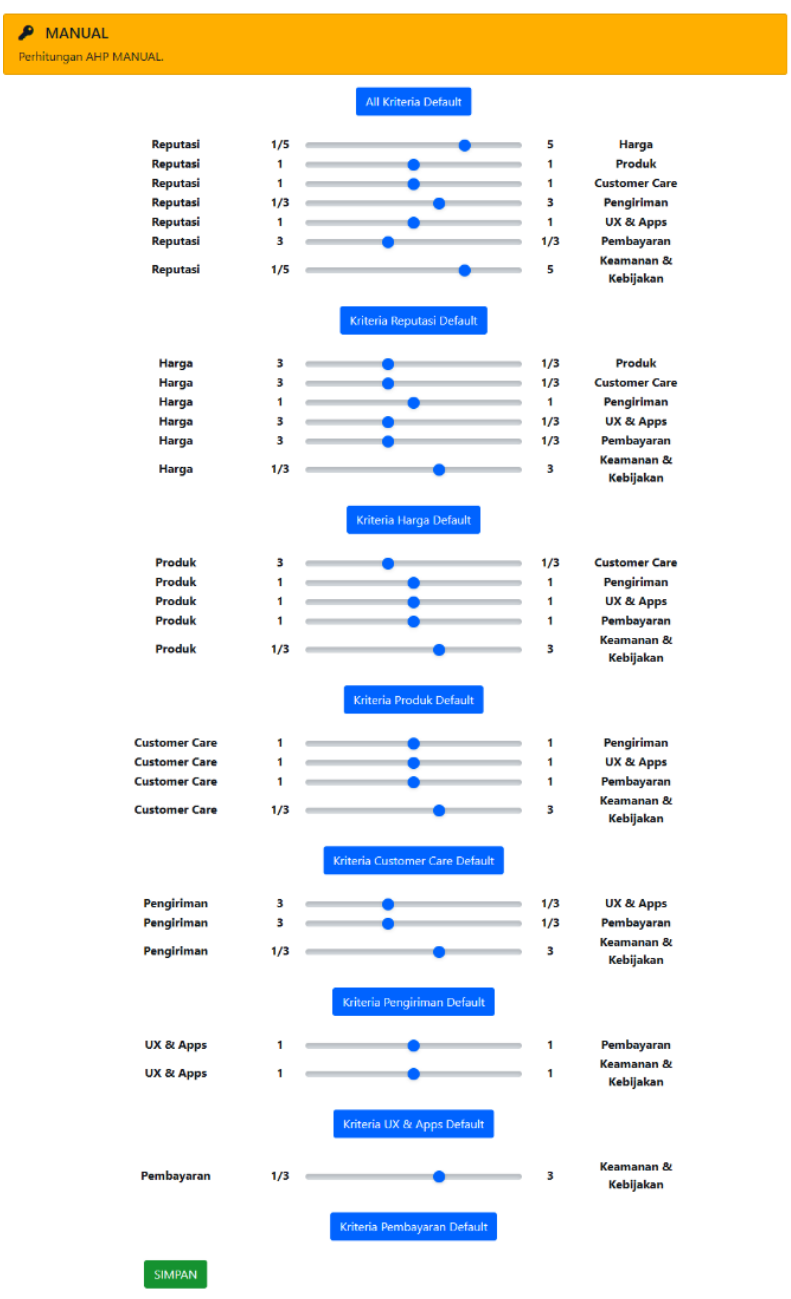

Gambar. 3 Implementasi Perbandingan Antar Kriteria oleh Narasumber 1

Tampilan implementasi matriks AHP yang telah diterjemahkan dengan skala Saaty pada narasumber 1 dapat dilihat pada gambar 4. Tampilan implementasi normalisasi pada metode AHP pada narasumber 1 dapat dilihat pada gambar 5. Tampilan implementasi eigen vector menggunakan metode AHP pada narasumber 1 dapat dilihat pada gambar 6 .

Tampilan implementasi data alternatif dapat dilihat pada gambar 7. Tampilan implementasi normalisasi menggunakan metode SAW dapat dilihat pada gambar 8 . Tampilan implementasi perhitungan normalisasi alternatif terbobot menggunakan AHP-SAW dapat dilihat pada 
gambar 9. Tampilan implementasi nilai preferensi menggunakan AHP-SAW dapat dilihat pada gambar 10.

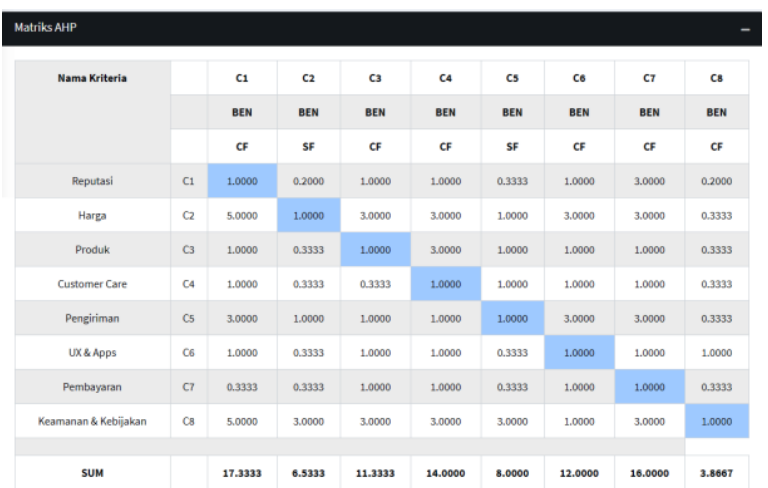

Gambar. 4 Implementasi Matriks AHP yang Telah Diterjemahkan dengan Skala Saaty pada Narasumber 1

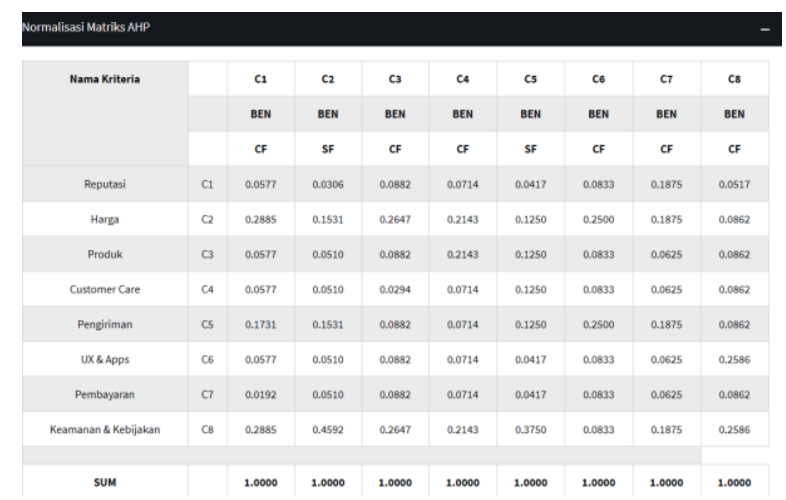

Gambar. 5 Implementasi Normalisasi pada Metode AHP pada Narasumber 1

\begin{tabular}{|c|c|}
\hline 三Eigen Vector & Nilai Kriteria \\
\hline Nama Kriteria & 0.0765 \\
\hline Reputasi & 0.1962 \\
\hline Harga & 0.0960 \\
\hline Produk & 0.0708 \\
\hline Customer Care & 0.1418 \\
\hline Pengiriman & 0.0893 \\
\hline UX \& Apps & 0.0630 \\
\hline Pembayaran & 0.2664 \\
\hline Keamanan \& Kebijakan & 1.0000 \\
\hline
\end{tabular}

Gambar. 6 Implementasi Eigen Vector Menggunakan Metode AHP pada Narasumber 1

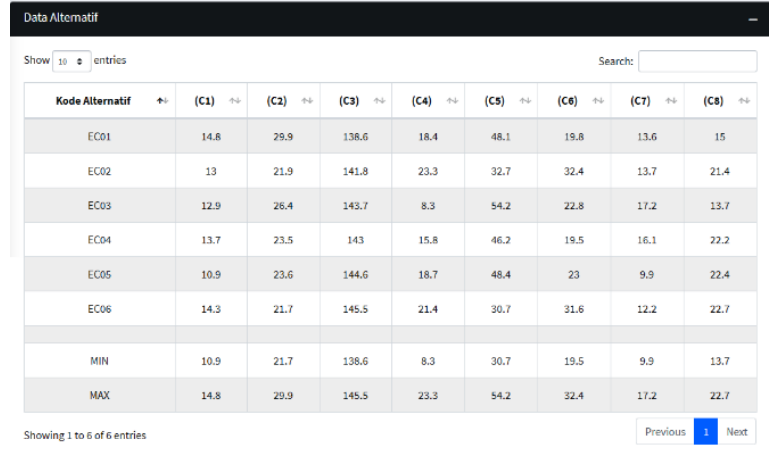

Gambar. 7 Implementasi Data Alternatif

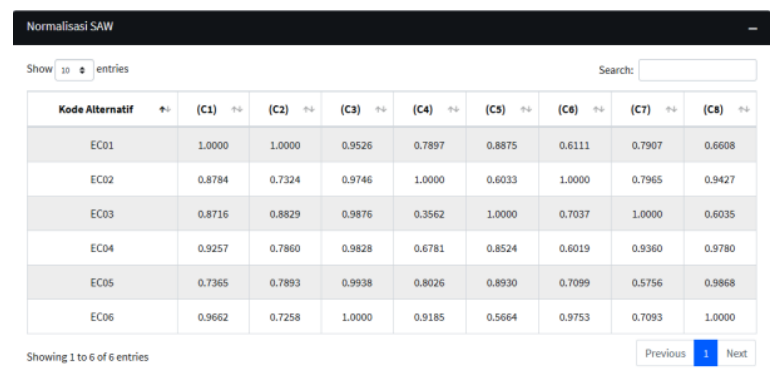

Gambar. 8 Implementasi Normalisasi Menggunakan Metode SAW

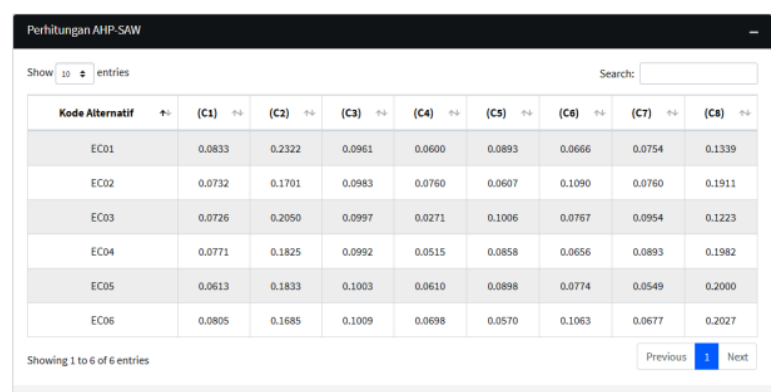

Gambar. 9 Implementasi Perhitungan Normalisasi Alternatif Terbobot Menggunakan AHP-SAW

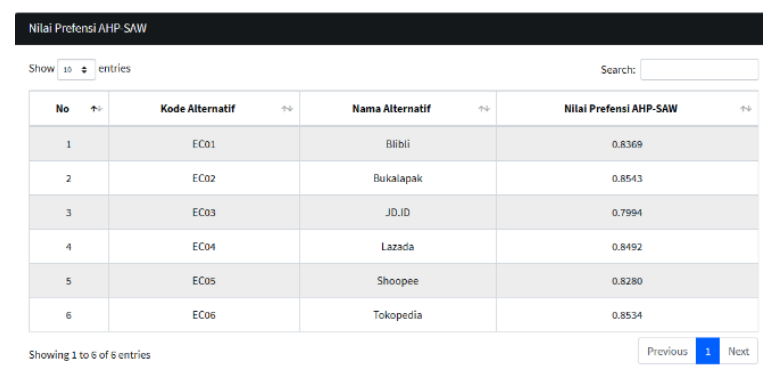

Gambar. 10 Implementasi Nilai Preferensi Menggunakan AHP-SAW

Tampilan implementasi normalisasi/ nilai vector menggunakan AHP-WP dapat dilihat pada gambar 11. Tampilan implementasi nilai preferensi menggunakan AHP-WP dapat dilihat pada gambar 12. Tampilan implementasi perbandingan nilai preferensi antara AHPSAW dan AHP-WP dapat dilihat pada gambar 13 . Tampilan implementasi perbandingan ranking antara AHPSAW dan AHP-WP dapat dilihat pada gambar 14 . 


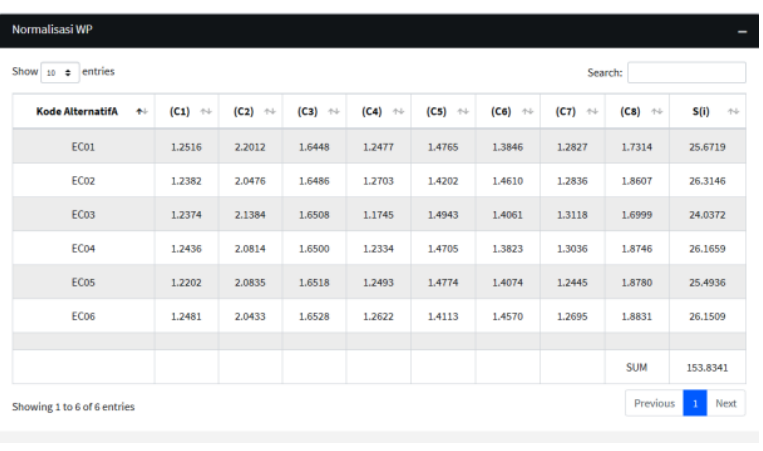

Gambar. 11 Implementasi Normalisasi/ Nilai Vector Menggunakan AHPWP

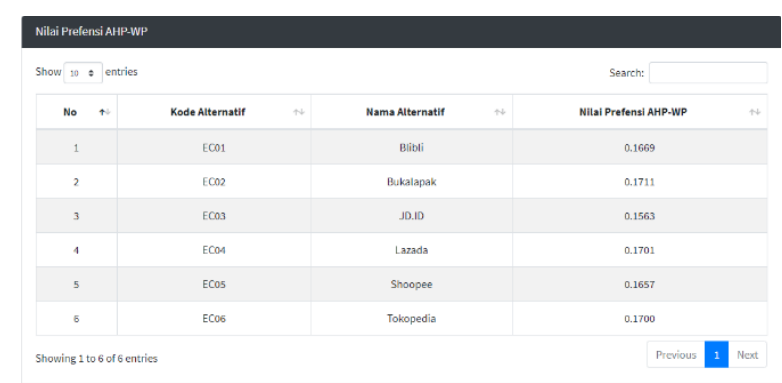

Gambar. 12 Implementasi Nilai Preferensi Menggunakan AHP-WP

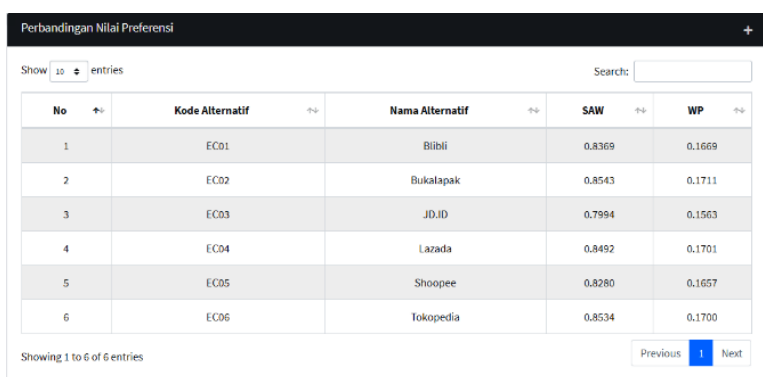

Gambar. 13 Implementasi Perbandingan Nilai Preferensi antara AHPSAW dan AHP-WP

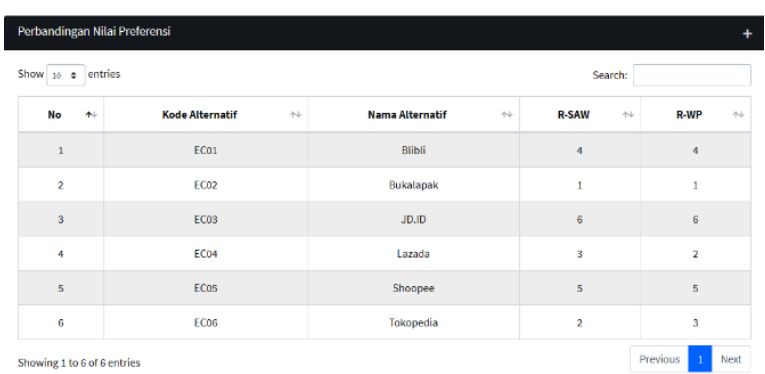

Gambar. 14 Implementasi Perbandingan Ranking antara AHP-SAW dan AHP-WP

\section{KESIMPULAN}

Berdasarkan penelitian yang telah dilakukan mengenai komparasi metode AHP-SAW dan AHP-WP pada SPK penentuan E-Commerce terbaik di Indonesia, dapat disimpulkan bahwa metode AHP-SAW dan AHP-WP dapat digunakan dalam penentuan E-Commerce terbaik di Indonesia, dapat dilakukan perhitungan secara manual dan diimplementasikan ke dalam perangkat lunak berbasis web. E-Commerce terbaik di Indonesia yang ditentukan berdasarkan pembobotan kriteria dari 5 narasumber yang aktif menggunakan E-Commerce dan penilaian alternatif berdasarkan survei eIQ Consumer Pulse 2019, menyatakan bahwa alternatif "Bukalapak" merupakan E-Commerce terbaik dengan Nilai preferensi AHP-SAW sebesar 0,8543 dan AHP-WP sebesar, 0,1711. Terdapat perbedaan ranking pada perhitungan AHP-SAW dan AHP-WP dimana peringkat ke-2 pada AHP-SAW adalah alternatif "Tokopedia" dan peringkat ke-3 pada AHP-WP adalah alternatif "Lazada", sedangkan peringkat ke-2 pada AHPSAW adalah alternatif "Lazada" dan peringkat ke-3 pada AHP-WP adalah alternatif "Tokopedia". Hal ini disebabkan pada tata cara normalisasi yang berbeda sehingga perbedaan yang sangat tipis tersebut membuat perbedaan hasil pada perankingan.

\section{UCAPAN TERIMA KASIH / ACKNOWLEDGMENT}

Terimakasih penulis ucapkan kepada STIMIK STIKOM Indonesia, atas pendanaan dalam program hibah penelitian pengembangan Dosen STIKI tahun pelaksanaan 2020, dengan nomor kontrak 07/04/LPPM/PPDS/VI/2020. Terimakasih kepada Tim Editorial Jurnal Nasional Teknologi \& Sistem Informasi yang telah memberikan kesempatan untuk penulis dapat menerbitkan artikel ini.

\section{DAFTAR PUSTAKA}

[1] Y. Pusparisa and S. Fitra, "96\% Pengguna Internet di Indonesia Pernah Menggunakan E-Commerce," katadata.co.id, 2019. https://databoks.katadata.co.id/datapublish/2019/12/03/96pengguna-internet-di-indonesia-pernah-gunakan-E-Commerce (accessed May 03, 2020).

[2] Y. Pusparisa and S. Fitra, "Transaksi E-Commerce Indonesia Terbesar di Asia Tenggara," katadata.co.id, 2019. https://databoks.katadata.co.id/datapublish/2019/10/10/nilaitransaksi-digital-perdagangan-elektronik-indonesia-terbesar-diasia-tenggara (accessed May 03, 2020).

[3] D. A. Widiastuti, "Covid-19 berdampak signifikan bagi $E$ Commerce," tek.id, 2020. https://www.tek.id/tek/covid-19berdampak-signifikan-bagi-ecommerce-b1ZLw9hAf (accessed May 03, 2020).

[4] S. Rongiyati, "Pelindungan Konsumen dalam Transaksi Dagang Melalui Sistem Elektronik," Negara Huk. Membangun Huk. untuk Keadilan dan Kesejaht., vol. 10, no. 1, pp. 1-25, 2019, doi: 10.22212/jnh.v10i1.1223.

[5] EIQ, "EIQ Consumer Pulse: Uncovering the Value of Indonesia's Top Online Platform," https://ecommerceiq.asia, 2018. ecommerceiq.asia/asp-products/eiq-consumer-pulse-uncoveringthe-value-of-indonesias-top-online-platforms/.

[6] D. F. Rohmiatullah, "Implementasi Metode Simple Additive Weighting dan Profile Matching dalam Pemilihan Lahan Tembakau (Studi Kasus: PTPN II - Kebun Bulu Cina)," Universitas Sumatra Utara, 2016.

[7] G. S. Mahendra and K. Y. E. Aryanto, "SPK Penentuan Lokasi ATM Menggunakan Metode AHP dan SAW," J. Nas. Teknol. dan Sist. Inf., vol. 5, no. 1, pp. 49-56, 2019.

[8] W. H. Rachman, J. A. Widians, and Masnawati, "Sistem Pendukung Keputusan Pemilihan Bibit Cabai Rawit Menggunakan Metode Simple Additive Weighting (SAW) Berbasis Web," in Prosiding Seminar Ilmu Komputer dan Teknologi Informasi, 2017, pp. $175-181$.

[9] S. Firdyana, D. Cahyadi, and I. F. Astuti, "Penerapan Metode Weighted Product untuk Menentukan Penerima Bantuan Beras Masyarakat Miskin (Raskin)," in Prosiding Seminar Ilmu Komputer dan Teknologi Informasi, 2017, pp. 336-342.

[10] N. M. R. M. Dewi, I. W. G. Narayana, and M. S. Wibawa, "Implementasi Metode AHP dan SAW dalam Penentuan 
Penerimaan Beasiswa Studi Kasus : ITB Stikom Bali," in Seminar Nasional Sistem Informasi dan Teknik Informatika, Sensitif 2019, 2019, pp. 1331-1340, [Online]. Available: https://ejurnal.dipanegara.ac.id/index.php/sensitif/article/downloa $\mathrm{d} / 530 / 465$.

[11] Arman, T. A. Sundara, I. Stephane, and M. Fadli, "Sistem Pendukung Keputusan Pemilihan Guru Terbaik dengan Metode Weighted Product Pada MAN 1 Pariaman," J. Inform., vol. 6, no. 2, pp. 310-321, 2019, doi: 10.32815/jitika.v11i2.219.

[12] I. Pratiwi and W. Andalia, "Perancangan Model Keputusan Multikriteria Pemilihan Layanan E-Commerce Untuk Kepuasan Pelanggan," in Seminar Nasional Sains dan Teknologi 2018, 2018, pp. $1-10, \quad$ [Online]. Available: https://jurnal.umj.ac.id/index.php/semnastek/article/view/3505/26 38.

[13] I. Pratistha, I. P. A. Mahadewa, and P. Sugiartawan, "Sistem Pendukung Keputusan Kelompok Pemilihan ECommerce/Marketplace Menggunakan Metode Profile Matching dan BORDA," J. Sist. Inf. dan Komput. Terap. Indones., vol. 1, no. 1, pp. 13-24, 2018, doi: 10.33173/jsikti.9.

[14] A. Setiyadi and R. D. Agustia, "Penerapan Metode AHP Dalam Memilih Marketplace E-Commerce Berdasarkan Software Quality and Evaluation ISO/IEC 9126-4 Untuk UMKM," J. IKRA-ITH Inform., vol. 2, no. 3, pp. 61-70, 2018.

[15] H. S. Setiawan and A. Pamuji, "Membangun Sistem Pendukung Keputusan Untuk Rekomendasi Pada E-Commerce Melalui Penerapan Logika Fuzzy Tahani," Fakt. Exacta, vol. 9, no. 4, pp. 341-352, 2016.

[16] M. Pradana, "Klasifikasi Bisnis E-Commerce di Indonesia," MODUS, vol. 27, no. 2, pp. 163-174, 2015, [Online]. Available: https://ojs.uajy.ac.id/index.php/modus/article/viewFile/554/580.

[17] J. E. S. Casym and D. N. Oktiara, "Aplikasi Analytical Hierarchy Process dalam Mengidentifikasi Preferensi Laptop Bagi Mahasiswa," in Seminar Nasional Teknologi Komputer \& Sains (SAINTEKS), 2020, pp. 636-640.

[18] M. F. Rozi, E. Santoso, and M. T. Furqon, "Sistem Pendukung Keputusan Penerimaan Pegawai Baru Menggunakan Metode AHP dan TOPSIS," J. Pengemb. Teknol. Inf. dan Ilmu Komput., vol. 3, no. 9, pp. 8361-8366, 2019.

[19] G. Mariscal, Ó. Marbán, and C. Fernández, “A survey of data mining and knowledge discovery process models and methodologies," Knowl. Eng. Rev., vol. 25, no. 2, pp. 137-166, 2010, doi: 10.1017/S0269888910000032.

[20] M. A. Rivai, "Analysis of Corona Virus spread uses the CRISPDM as a Framework: Predictive Modelling," Int. J. Adv. Trends Comput. Sci. Eng., vol. 9, no. 3, pp. 2987-2994, 2020, doi: 10.30534/ijatcse/2020/76932020.

[21] R. Wirth and J. Hipp, "CRISP-DM : Towards a Standard Process Model for Data Mining," Semant. Sch., vol. 1, no. 24959, pp. 1-11, 2000, [Online]. Available: https://www.semanticscholar.org/paper/Crisp-dm\%3A-towards-astandard-process-modell-for-WirthHipp/48b9293cfd4297f855867ca278f7069abc6a9c24. 